\title{
The Impact of Transit-Oriented Development on Fast-Urbanizing Cities: Applied analytical study on Greater Cairo Region
}

${ }^{1}$ MS.c. Mohamed Kafrawy (D), 2 Professor Dr. Sahar Attia (i) P , 3 Professor Dr. Heba Allah Khalil (iD P

1, 2 \&3 Department of Architecture, Faculty of Engineering, Cairo University, Egypt

1E-mail: en.kafrawy@gmail.com,2E-mail: saharattia16@eng.cu.edu.eg,3E-mail: hebatallah.khalil@gmail.com

\section{ARTICLE INFO:}

\section{Article History:}

Received: 16 May 2021

Revised: 25 August 2021

Accepted: 27 August 2021

Available online: 8 September 2021

\section{Keywords:}

Transit-oriented

Development;

Fast-Urbanizing cities;

Sustainable

transportation;

Sustainable

development;

Greater Cairo region.

\section{This article is an open access}

article distributed under the terms and conditions of the Creative Commons Attribution (CC BY) license

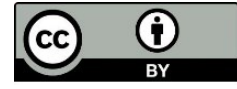

This article is published with open access at www.ijcua.com

\section{ABSTRACT}

ᄃ) Check fo Updates

Transportation has always been the backbone of development. Transitoriented development (TOD) has been theorized, piloted and expanded increasingly in the past few decades. In this regard, this paper investigates the relationship between urban development, the transportation process, and the required implementation guidelines within fast-urbanizing cities, such as Cairo. After reviewing different related sustainable development theories, the study investigates pioneering case studies that have applied TOD and provided adequate implementation frameworks. The authors then extract and compare a set of required policies. The current Egyptian development paradigm is then discussed in relation to these enabling policies, focusing on Greater Cairo Region, Egypt. The authors debate previous development plans, progress, and newly proposed ones, focusing on the transportation process as the means for development. The study concludes with a set of required guidelines to ensure the integration of transportation with land-use planning, thus ensuring a more prosperous and inclusive urban development.

JOURNAL OF CONTEMPORARY URBAN AFFAIRS (2022), 6(1), 83-95. https://doi.org/10.25034/ijcua.2022.v6n1-8

WWW.ijcua.com

Copyright (c) 2021 by MS.c. Mohamed Kafrawy, Professor Dr. Sahar Attia \& Professor Dr. Heba Allah Khalil.

\section{Introduction}

In order to improve the intense and complex relationship between urban planning and transportation networks, several urban development theories have been established in the last decades (Kaufmann, 2011; Mishra, 2019). Smart Growth, New Urbanism and TOD are different examples of these theories, where their methods tried to introduce a clear successful model of this relationship. However, in many cities of the Global South, the relation between urban planning, specifically land use planning and transportation planning is lacking (Yang et al., 2021). In addition to the isolation

\footnotetext{
*Corresponding Author:

Department of Architecture, Faculty of Engineering, Cairo University, Egypt

Email address: en.kafrawy@gmail.com
} 
of planning across transport modes (Mahendra, 2018). Hence, the objective of the study is to provide a specific framework explaining how to apply TOD techniques in Greater Cairo Region (GCR), including clear policies and realistic guidelines ensuring that the mentioned framework will be applicable and available for implementation. A major emphasized point is that the exported framework shall be developed through reviewing global case studies, which successfully apply the TOD principles.

\section{Methodology}

To address the paper's objective, the paper used triple-fold analysis. First, the study devised an inductive method to analyse different theories related to sustainable urban development and transportation. Then, the study conducted a comparative analysis to compare the attributes of the chosen theories determining the main differences. Second, the paper reviewed international pioneer case studies which successfully applied TOD principles as the chosen theoretical framework. The paper selected three case studies with different contexts, including developed and developing countries. Through the analysis of the three cases, the study extracted the relevant policies that were implemented. This review allowed the study to export a clarified strategy for how the TOD applications can/shall be implemented in any new country. Third, the paper critically analysed transportation in GCR relying on published reports and studies. After reviewing the current public transportation situation in GCR and previous suggestions for public transportation, the paper analysed these suggestions in comparison to the principles of TOD. The paper then used a deductive method to provide a specific framework explaining how to apply TOD techniques in GCR. Finally, the authors conducted a pilot study to apply TOD principles in two cities within GCR. Consequently, relevant conclusions and recommendations were developed proposing a strategy to apply TOD principles in the Greater Cairo Metropolitan Area as one of the available solutions that address multiple issues such as pollution, overcrowding, traffic accidents, the lack of transit services, natural resources destruction, greenhouse gas emissions, energy crisis, and visual intrusion, with the possibility to apply TOD worldwide (Figure 1).

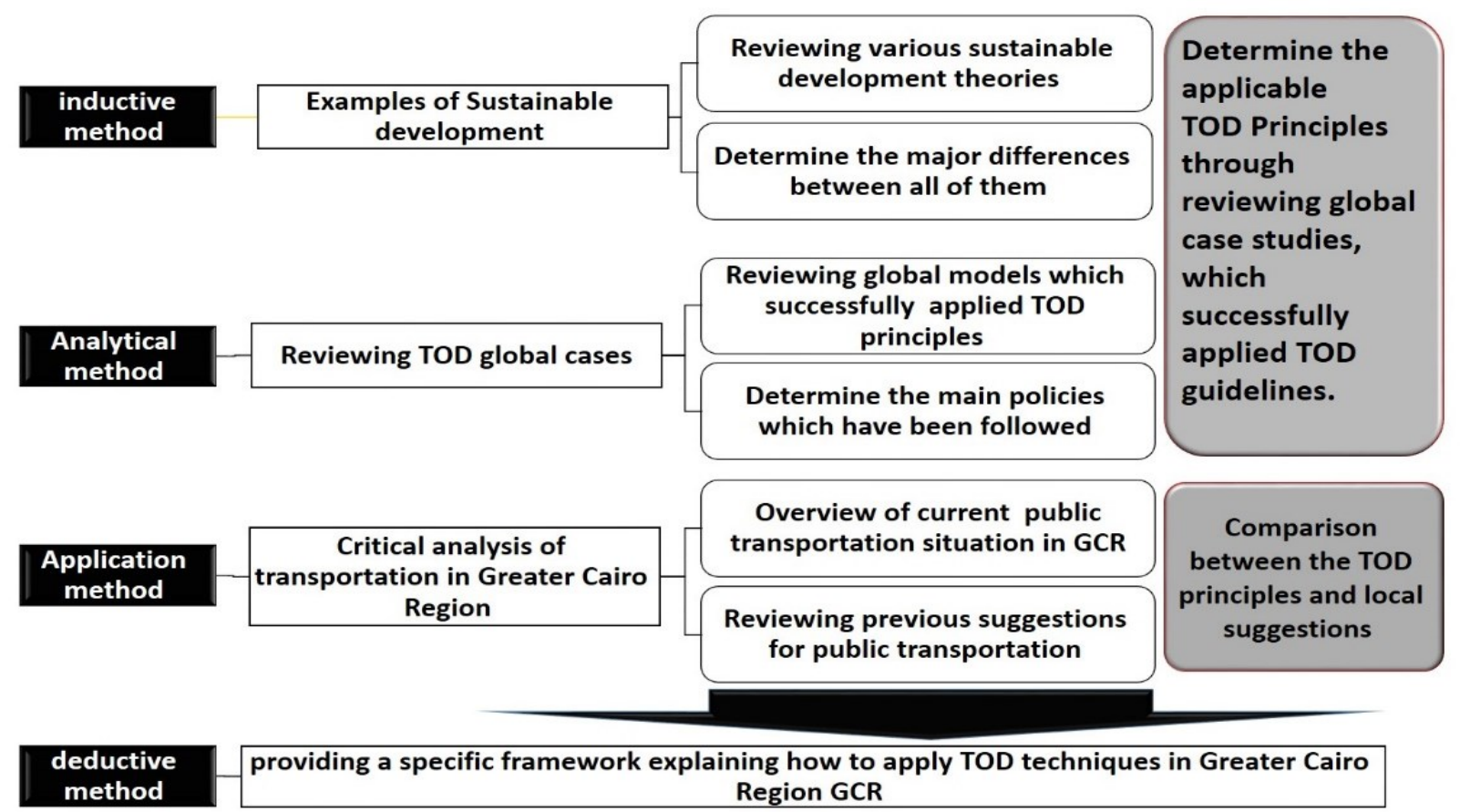

Figure 1. Methodology of the study (Developed by the Authors). 


\section{Examples for sustainable development theories}

The emergence and development of various types of urban planning movements, after 1980, are all attempts to provide a physical model for the realization of a sustainable city. These theories have many similarities and differences, but common principles exceed differences. The most important theories that relate to sustainable urban planning are Compact city (Newman \& Kenworthy, 1989), Smart Growth (Stoel, 1999), New Urbanism (Hasic, 2000), Transit-oriented Development (Boarnet \& Crane, 2001), Decentralized Concentration (Breheny, 1996; Holden, 2004; Høyer \& Holden, 2003), Sustainable Urbanism (Farr, 2011), and Urban Renaissance (Downs, 2005).

\subsection{Smart Growth}

Several community authorities, institutions, and government agencies have provided different definitions for smart growth, but each one has done that through its perspective and primary references. As a result, no unified definition for smart growth was reached, but rather a group of missions and goals. However, most of them have agreed on the major guidelines and basics of natural resources preservation. Healthy environment, wildlife conservation, green space, open space, clean air, farmland and clean water, all of these elements were the most important and common aspects of the smart growth concept (Ye et al., 2005). Smart Growth can be seen as a group of policies, which may be implemented in several diverse ways. In rural areas, it provides mixed- use, pedestrian villages with different types of housing units around a retail centre. In a huge community, the mentioned type of sustainable development can be intensive, represented by urban neighbourhoods with a large towers that have been established around main transit stations. In both types, there are different neighbourhood concepts, however; their common theme is compactness (Litman, 2015).

\subsection{New Urbanism}

New Urbanism first appeared in European countries under a different title "Urban Villages", but afterwards the new planning direction was able to find a place in the Congress of European Urbanism (CEU). Prince Charles introduced it in the beginning in England (Stefan, 2005). The first definition of new urbanism contained diversity, pedestrian scale, public space and structure. It is a planning movement, which advocates design based on traditional urban form strategies to restrict suburban sprawl and inner-city decline, and to construct and re-construct neighbourhoods, towns, and cities (Iravani \& Rao, 2020). In other words, New Urbanism is a comprehensive definition that concentrates on the traditional neighbourhood development, or "neo-traditional" town planning. It also presents an interactive model, as all its principles and components (as shown in Figure 2), which were prepared previously in Smart Growth, have been reintroduced with more specific standards that were tools to turn the smart growth from a theory into a physical model (Iravani \& Rao, 2020).

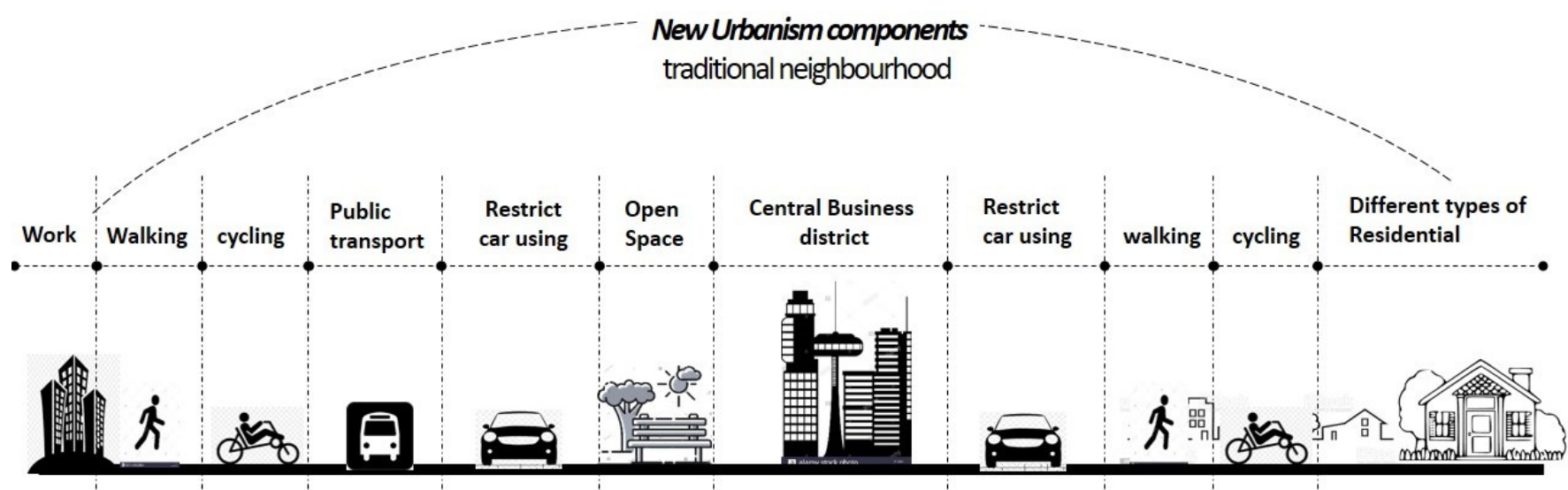

Figure 2. Daily trips in new urbanism - source the Authors.

\subsection{Transit-Oriented Development}

The mixed-use development area around mass-transit facilities has been defined as a
"Transit-oriented Development" or TOD. This movement also drew attention to some urban contents which were matching with those of 
Smart Growth or New Urbanism. However, the additional point in TOD is the planning or replanning of the spaces near stations into development hubs, thus, highlighting the urgency for this type of development (De Vos et al., 2014; Transit Cooperative Research Program, 2002). TOD principles often depend on promoting transit-use through planning pedestrian, mixeduse core and a less intensely developed secondary area, with a mass-transit stop, Centre or Station. TOD is a planning approach that promotes the area around transit stations for people to live and work, in the hope of decreasing their dependence on driving (Youzhen \& Longlong, 2012) (Figure 3).

Table 1 presents a comparison between these 3 theories regarding the main commonalities and differences.

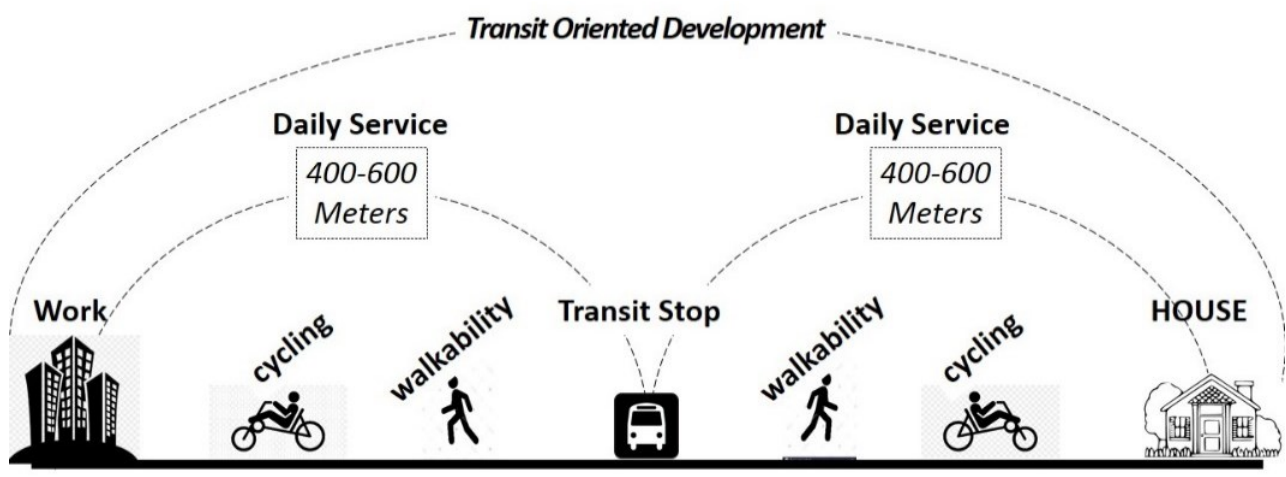

Figure 3. Designation for TOD area around Transit Stop - The Authors based on (Dock \& Swenson, 2003).

Table 1. comparison between sustainable development theories (The Authors based on various sources as detailed below).

\begin{tabular}{|c|c|c|c|}
\hline Major Elements & Smart Growth & New Urbanism & TOD \\
\hline Main difference & $\begin{array}{l}\text { It started as a theoretical } \\
\text { idea without specific } \\
\text { standards or applied } \\
\text { project. (Porter, 2002). }\end{array}$ & $\begin{array}{l}\text { It transformed theoretical ideas into } \\
\text { a realistic project, according to } \\
\text { specific standards. (Stefan, 2005) }\end{array}$ & 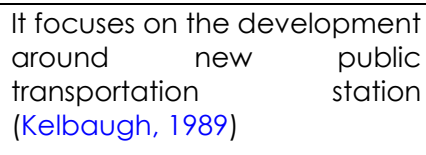 \\
\hline Pedestrian-friendly & $\begin{array}{l}\text { Supporter but no specific } \\
\text { strategies or design tools } \\
\text { (MacLeod, 2013) (Ye et al., } \\
\text { 2005) }\end{array}$ & $\begin{array}{l}\text { The distance between most uses } \\
\text { and any other destination shall not } \\
\text { be more than 10-minute by } \\
\text { walking (Stefan, 2005) }\end{array}$ & $\begin{array}{l}\text { The best area for pedestrian } \\
\text { design is the distance people } \\
\text { walk from home to a transit } \\
\text { stop, which shall be not more } \\
\text { than } 400-600 \text { meters (Dock \& } \\
\text { Swenson, 2003). }\end{array}$ \\
\hline Open Space & $\begin{array}{l}\text { Supporter but no specific } \\
\text { strategies or design tools } \\
\text { (MacLeod, 2013). }\end{array}$ & $\begin{array}{l}\text { It adds a clear framework to } \\
\text { protect open space(MacLeod, } \\
\text { 2013) }\end{array}$ & $\begin{array}{l}\text { The transit hub is taken as the } \\
\text { centre to provide open space, } \\
\text { (Youzhen \& Longlong, 2012). }\end{array}$ \\
\hline $\begin{array}{l}\text { Mixed land use } \\
\text { development }\end{array}$ & $\begin{array}{l}\text { It is an important element } \\
\text { but still focuses on the } \\
\text { general framework } \\
\text { (MacLeod, 2013), (Ye et al., } \\
\text { 2005).. }\end{array}$ & $\begin{array}{l}\text { Mixed-use development is } \\
\text { designed to be within the distance } \\
\text { between work and home (Nyström } \\
\text { \& Fudge, 1999). }\end{array}$ & $\begin{array}{l}\text { The land near the transit hubs } \\
\text { has been used as a centre } \\
\text { point for mixed land use } \\
\text { development (Youzhen \& } \\
\text { Longlong, 2012). }\end{array}$ \\
\hline Smart Transportation & $\begin{array}{l}\text { Supporter but no specific } \\
\text { strategies or design tools } \\
\text { (Ye et al., 2005) }\end{array}$ & $\begin{array}{l}\text { The connection of all urban } \\
\text { communities by high-qualified rails } \\
\text { is one of the urgent targets in this } \\
\text { sustainable development type. } \\
\text { Also encouraging greater use of } \\
\text { public transportation (Stefan, 2005) }\end{array}$ & $\begin{array}{l}\text { All types of public } \\
\text { transportation, whether } \\
\text { intended to connect the } \\
\text { railway network or the quality } \\
\text { of service, are the focus of this } \\
\text { type of development. (Dock \& } \\
\text { Swenson, 2003). }\end{array}$ \\
\hline
\end{tabular}

\subsection{Models of Transit-Oriented development}

Similar challenges were faced in the studied models. However, the various approaches for providing guidelines and a mix of policy tools have been brought up to the forefront as a result of the analysis of global TOD best practices. The three cities across the world that have been chosen, are in different countries and each one of them has its unique circumstances and challenges. For example, the paper discusses the city of Curitiba, Brazil, a developing country, unlike the other two models, Vienna in Austria, and Los Angeles in the USA. To further elaborate the case study selection process, one of the main criteria was 
that sustainable transportation was strongly enforced in all of them.

A major point is that there isn't a "One Size Fits All" approach for TOD. By reviewing the sustainable transportation principles in several European countries, it became remarkably clear that TOD appeared under different names and with minor changes in applications (Pojani \& Stead, 2016). For Example, one of the sustainable transport requirements is achieving mixed-use development and medium-to-high densities; all of these are the main objectives in the TOD. Moreover, there is no way for applying sustainable urban transport principles without following TOD measures. In the end, they are all moving on the same track, and are two sides of the same coin (United Nations, 2010, 2016), The main applications of TOD have been studied in many previous global cases, and many documents were carefully inspected alongside the most important policies. The result is summarized for the main aspects that represent the backbone of TOD applications, as per the following points shown in Table 2.
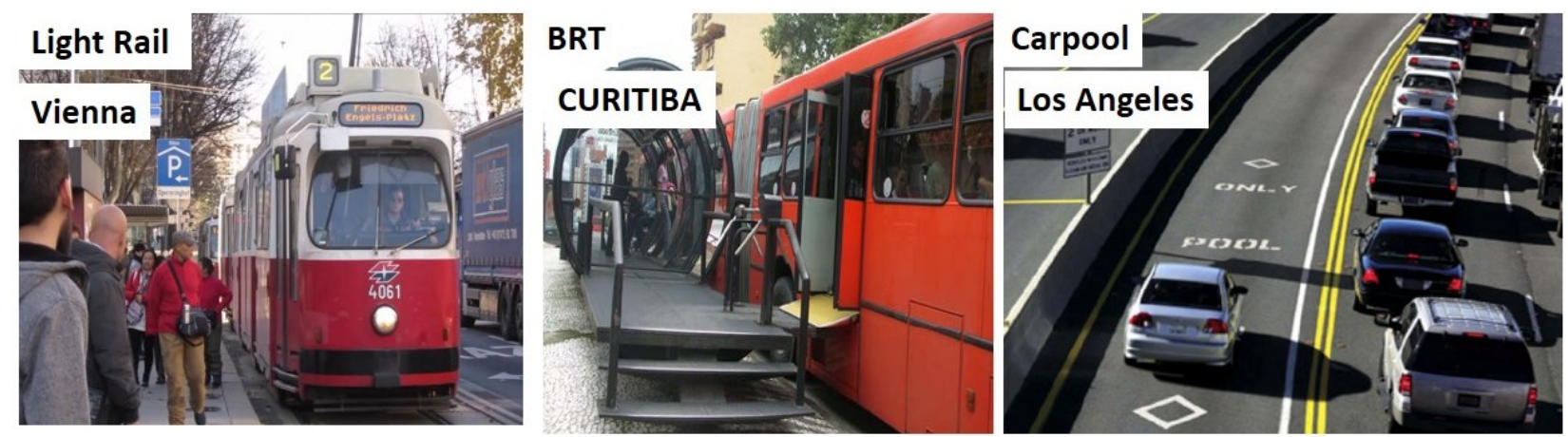

Figure 4. The distinctive TOD ideas in each of the case studies - Source (IPPUC, 2000) (GJEL, 2015).

Table 2. Sustainable transport and TOD policies.

\begin{tabular}{|c|c|c|c|}
\hline $\begin{array}{l}\text { Implemented } \\
\text { tactics }\end{array}$ & Vienna & Curitiba & Los Angeles \\
\hline $\begin{array}{l}\text { Integration } \\
\text { between all } \\
\text { public transport } \\
\text { types }\end{array}$ & $\begin{array}{l}\text { Integration between S-Bahn } \\
\text { and U-Bahnfigur4 (Sammer, } \\
\text { 2015, May 8-15) (Knoflacher, } \\
\text { 2015, May 5). }\end{array}$ & $\begin{array}{l}\text { RIT (Rede Integrada de } \\
\text { Transporte) or the BUs Rapid } \\
\text { Transport System BRT idea } \\
\text { represented a } \\
\text { comprehensive integration } \\
\text { system (IPPUC, 2000) }\end{array}$ & $\begin{array}{l}\text { Integration between Los } \\
\text { Angeles's light rail and rapid } \\
\text { bus corridors. (CTOD, 2010) }\end{array}$ \\
\hline $\begin{array}{l}\text { Integration } \\
\text { between land } \\
\text { use and } \\
\text { transport } \\
\text { planning }\end{array}$ & $\begin{array}{l}\text { Extending of combined mixed- } \\
\text { Use around Vienna's Main Train } \\
\text { Station (Sammer, 2015, May 8- } \\
\text { 15) (Madreiter, 2015, May 11), }\end{array}$ & $\begin{array}{l}\text { Integration between land } \\
\text { use and transport planning } \\
\text { was one of the main goals } \\
\text { for the master plan (IPPUC, } \\
2000 \text { ) }\end{array}$ & $\begin{array}{l}\text { Prioritize new development for } \\
\text { achieving coordinated land } \\
\text { use and transport planning } \\
\text { (CTOD, 2010).. }\end{array}$ \\
\hline $\begin{array}{l}\text { Improving } \\
\text { walking and } \\
\text { cycling } \\
\text { conditions }\end{array}$ & $\begin{array}{l}\text { Some streets became shared } \\
\text { with a } 20 \mathrm{~km} / \mathrm{h} \text { speed, } \\
\text { pedestrians and cyclists also } \\
\text { having the same right as } \\
\text { motorists (Vassilakou, 2015, May } \\
\text { 9) (Maresch, 2015, May 13) }\end{array}$ & $\begin{array}{l}\text { Structure corridors that } \\
\text { promoted walking and } \\
\text { cycling, the municipality } \\
\text { also gave people better } \\
\text { opportunities to ride } \\
\text { bicycles inside the city } \\
\text { (IPPUC, 2000) }\end{array}$ & $\begin{array}{l}\text { Using small blocks and } \\
\text { avoiding mobility barriers } \\
\text { provided local options for } \\
\text { accessibility by walking or } \\
\text { biking. (CTOD, 2010) }\end{array}$ \\
\hline $\begin{array}{l}\text { Discouraging } \\
\text { the increasing } \\
\text { growth of } \\
\text { private } \\
\text { motorized }\end{array}$ & $\begin{array}{l}\text { Raising gasoline prices, taxes on } \\
\text { owed cars, and an increase in } \\
\text { the prices of driving licenses } \\
\text { (IEA, 2015). }\end{array}$ & $\begin{array}{l}\text { Restrictions for } \\
\text { dependence on private } \\
\text { car regulations were very } \\
\text { weak (Klink \& Denaldi, 2011) }\end{array}$ & $\begin{array}{l}\text { Restrictions for dependence } \\
\text { on private car regulations } \\
\text { were weak compared to } \\
\text { Western Europe (Buehler et } \\
\text { al., 2017). }\end{array}$ \\
\hline $\begin{array}{l}\text { Promoting an } \\
\text { affordable and } \\
\text { accessible } \\
\text { public } \\
\text { transportation }\end{array}$ & $\begin{array}{l}\text { Expansion of the U-Bahn and S- } \\
\text { Bahn systems beside improving } \\
\text { all types of public transport } \\
\text { since } 1990 \text { (Bohrn \& Buehler, } \\
2015 \text { ) }\end{array}$ & $\begin{array}{l}\text { Expansion of ternary road } \\
\text { system and bi-articulated } \\
\text { buses beside another } \\
\text { system to cover most of the } \\
\text { city. (Figure 4) (IPPUC, 2000) }\end{array}$ & $\begin{array}{l}\text { Expansion of rail projects and } \\
\text { provide a travel time } \\
\text { advantage for each of } \\
\text { carpools and vanpools } \\
\text { (Figure 4) (CTOD, 2010) }\end{array}$ \\
\hline $\begin{array}{c}\text { Parking } \\
\text { management }\end{array}$ & $\begin{array}{l}\text { The parking management } \\
\text { federal regulations were set to }\end{array}$ & $\begin{array}{l}\text { Parking regulations were } \\
\text { weak, but the high level of }\end{array}$ & $\begin{array}{l}\text { The planning Commission } \\
\text { urged the City Council to use }\end{array}$ \\
\hline
\end{tabular}




\begin{tabular}{|c|c|c|c|}
\hline $\begin{array}{l}\text { Implemented } \\
\text { tactics }\end{array}$ & Vienna & Curitiba & Los Angeles \\
\hline & $\begin{array}{l}\text { avoid car choice as a method } \\
\text { for movement (Herry, 2015, } \\
\text { May 12) (Sammer, 2015, May 8- } \\
\text { 15) (Riedel, 2014) }\end{array}$ & $\begin{array}{l}\text { crime and car theft made } \\
\text { owning/using a car a bad } \\
\text { choice (Klink \& Denaldi, } \\
2011)\end{array}$ & $\begin{array}{l}\text { parking maximums, pooled } \\
\text { parking and automated } \\
\text { stacked parking as a basis for } \\
\text { new city ordinances (CTOD, } \\
2010 \text { ) }\end{array}$ \\
\hline $\begin{array}{l}\text { Discounting } \\
\text { Fare policy. }\end{array}$ & $\begin{array}{l}\text { Several policies for discount } \\
\text { transit tickets including all } \\
\text { residents and workers } \\
\text { categories (Ossberger, 2015, } \\
\text { May 8) }\end{array}$ & $\begin{array}{l}\text { Unifying a ticket price as } \\
\text { one fare will be enough to } \\
\text { use on transit systems } \\
\text { (IPPUC, 2000) }\end{array}$ & $\begin{array}{l}\text { Discounting Fare policy } \\
\text { expanded to include most } \\
\text { types of residents and } \\
\text { electronic payment (LADOT, } \\
2015 \text { ) }\end{array}$ \\
\hline
\end{tabular}

As per the previously discussed policies, transitoriented development or sustainable transport not only concentrates on public transportation but also takes into consideration the relationship between transit systems and all other elements that should be integrated with them. Each one of the mentioned seven axes represents an important stage in the TOD system, so in the following part, the study will compare the current proposed general strategy for Greater Cairo Region with the previously discussed policies.

\section{Application of TOD strategy in GCR 4.1. Overview}

In the Greater Cairo Region, $68 \%$ of all daily trips are done by public transportation. Out of all public transport trips, $52 \%$ are done by shared minibuses (known as microbuses), $25 \%$

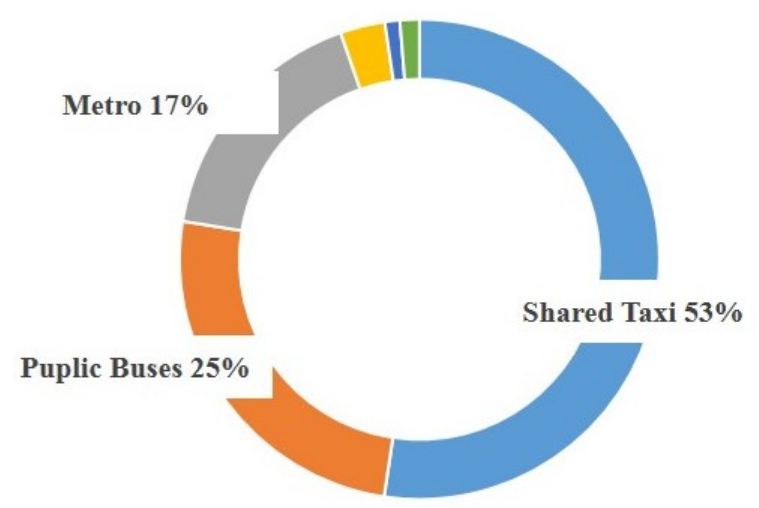

by public buses and just $17 \%$ by metro, (Figure 5). Although this study was conducted almost 20 years ago, still the share of informal transportation modes is accurate, if not increased. The current situation in Greater Cairo Region has become very complicated with no apparent simple solution. Isolated solutions did not bring any actual success, because there is a need to establish a comprehensive system, rearranging all relevant measures into one coherent strategy with all contingency measures. The GCR is still suffering from many issues such as serious traffic congestion, poor passenger transport system, high accident rate, air and noise pollution, institutional weaknesses and fragmentation and inadequate financial arrangements (World Bank, 2006).

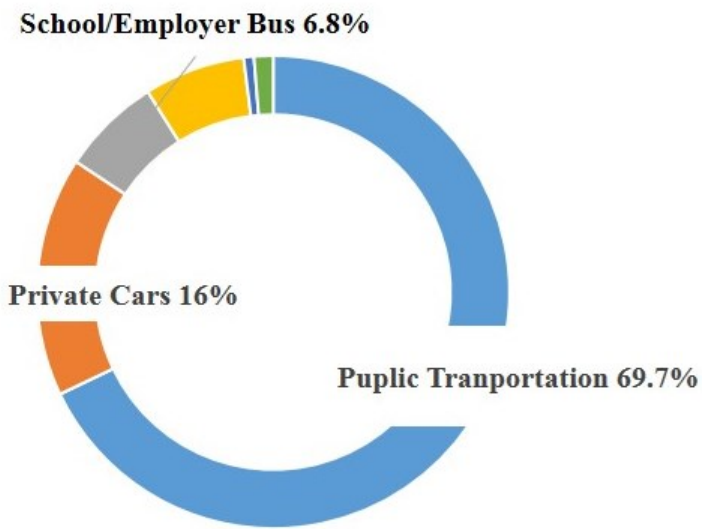

Figure 5. Trip generation pattern- source (JICA, 2002).

More people living in Cairo are choosing the private car as a perfect mode to travel, which resulted in a major change, in recent years, in the used means for total daily trips. Private motorized vehicles usage is increasing every day as a percentage of the total numbers of Greater Cairo daily trips. The proportion of public buses trips has also decreased, because a large number of users have left this option and started switching to informal taxis and minibuses as an effective and affordable new option. This was a logical result of the fact that there was no development or improvement in public buses daily services. Moreover, the percentage of public buses users lost more than twenty percent, from its original forty percent in only ten years despite economy fares. Likewise, most of the tram services have 
gone out of operation gradually as investments and periodic maintenance did not balance with the service value. As a result, the second logical step was increasing the demand for the metro system; but still, the largest part of the daily trips demand was for taxis and shared microbuses as the percentage of these types increased by more than $50 \%$ of all public transport trips (JICA, 2002).

\subsection{Analysis of previous studies}

Among the most recent studies that have been introduced in the last decades are the "Urban Planning Restructure for Greater Cairo Region" in 2014, and "Greater Cairo: a proposed urban transport strategy" in 2006. A critical issue here was that the focus of the first study was on urban planning while the second focused more on the transportation master plan. The objective of the second study was to add a comprehensive strategy for the urban transport system in GCR, which was more in synchronization with the objectives of TOD. A specific general plan for clarifying and determining the actual measures and investment priorities has been introduced as one of many other solutions, which would be the basis of a formal transport strategy. Following that, there were seven strategic areas of intervention of a mix of policy actions and priority investments. In the next section of the paper, the comparison between the mentioned proposed seven strategies and seven TOD policies, exported from the previously analysed global models, shall be discussed, thus, proposing a method for how the government can apply TOD in Cairo.

\section{i.Developing and sustaining urban} transportation institutions: As per the previous discussion, the current transportation situation in Greater Cairo is extremely complex. In addition, the official institution created to manage public transportation is not ready to deal with this kind of mega-city like GCR. All employees who have been appointed to manage the aforementioned subject have not been trained or upgraded to be more qualified and able to succeed in their mission. So, the first strategy focused on providing official institutions with relevant roles that match their employees, policies, and general plans (World Bank, 2006).

Although this point is very critical and global models have already been made, yet it doesn't come as one of the policies for TOD. This is a result of an underlying logic that qualified institutions would apply sustainable principles.

ii.Review decision-making stage, as the choice for appreciating investments alternatives, should be more matching and balancing with the financial transport sector plan: By reviewing the governmental direction of transport in subway lines and the maximum potential capacity of an existing roadway in the last twenty years, it became remarkably clear that there was no balance between transportation demands and services and investments. Hence, it is extremely necessary in this strategy to emphasize effective decision making, and prioritization of investment based on objective criteria (World Bank, 2006).

This strategy not only matches but also confirms the fifth previously mentioned policy as both promote an effective, affordable, physically accessible, and environmentally sound public transport and communication system.

iii.Determining the public transport fare to comply with operating costs and without pressure on the poor stratum of the community: In general, the fare policy needs more in-depth study, as the current tariff of all tickets is low and does not match the actual service provided to all passengers. On the other hand, the low cost represents an attractive public transport tool for all people. Hence, the structure of the fare policy must be redesigned, where the ticket discounts are directed towards those who need them, while all other users shall pay the regular tariff without any subsidization (World Bank, 2006) . The authors believe that this point shall complement the previous strategy, as there is no way to improve public transportation without introducing a clear financing system. However, this will be applied with a balance between maintaining affordability on the one hand for all poor and low-income commuters and on the other hand fair prices for commuters with medium and high incomes. Hence, the seventh TOD policy has been introduced as a specific solution for this issue. 
iv.Develop the public transport services to meet the needs of the passenger: because of the general inadequacy of public transport revenues, the number of investments by the government to improve the service was also inappropriate. In addition, the attempt to provide an affordable and efficient transit service was not always satisfactory to the passengers. Hence, the emergence of the private sector and the introduction of public transport service alternatives that match the passenger's needs was a logical result. Therefore, the fourth strategy here gave special importance to restructuring the public transport system to improve its organization.

By reviewing the previous four strategies mentioned above and comparing them to the sustainable transportation requirements, it shall be made remarkably clear that these strategies can be combined as one policy, which shall be the same in Table 2 under the name "promoting public transport and communication system". However, GCR Strategies shall have more added details on how reinforcement and improvement can be applied.

\section{v.Modernized effective traffic management} system: All the objectives, that were expounded in this strategy focus on special measures, that would help in addressing the traffic congestion by decreasing the traffic flow in comparison with road capacity. However, these measures act as tools rather than policies, such as using signalized intersections, redesigning for pedestrians around the intersection, applying solid parking management rules, and considering on-street bus operation as a priority to name just a few. This strategy shall be applied side by side with the fourth sustainable transport or TOD policy, since the major objective shall be addressing the traffic congestion with emphasis on discouraging the increase in growth of private motorized traffic as well as congestion reduction.

vi. Application of proactive travel demand management techniques: Although the car use restrictions and parking demand management became policies that have been applied in several international cities, both are still missing rules in GCR. Hence, instead, some measures shall be applied to help decrease car dependency such as prohibiting car parking in certain areas, increasing parking chargers, tolling selected roads and cordon pricing to permit entry into designated high-density areas. Focusing on proposing integrated applications, that explain how the proactive travel demand management techniques can be applied, shall be the main point in the sixth strategy. There is no major difference between this strategy and the main axis that has been discussed in the sixth policy of the TOD, as the restriction of car usage without doubt shall reflect on the demand of parking lots and development of parking lots management.

\section{vii.Provide an independent institution to strictly} apply traffic policies: Once again, this strategy emphasizes the fact that implementing traffic and demand management is deemed to fail if it is done as a separate measure because success initially depends on strong and rigorous applications. Therefore, the implementation of this policy needs clarification and comprehension. The seventh strategy shall provide a set of policies to be concluded as an integrated strategy, including a different organizational structure and a change in the perception of the users that represent two policies of the said layer. Thus, resulting in less police involvement in traffic. Treating this strategy as an individual item, not related to the above policy, that in turn focuses more on the restriction of car dependence or parking management, would be a major error. The fifth, sixth and seventh strategies shall be gathered in one group under the name "traffic management unit". This proposal came as a result based on the comparison between these strategies with others in TOD policies.

In spite of the fact that the study succeeded in introducing applicable models and exporting logical methodology to improve the public transportation system, yet what is still missing is the consideration that both urban planning and public transport will move in different directions. This contradicts TOD that deals with all of them as one entity and considers the integration between land use planning and public transportation network an urgent policy to achieve success for both. 


\subsection{A pilot study to apply TOD in different parts of GCR}

\subsection{1. $6^{\text {th }}$ of October City, GCR}

One of the most important issues in new Egyptian cities is the reliance on the informal sector as the main mode of travel. For example, the specially modified, privately operated, pick-up van, where two longitudinal seats have been added in the back part under a metallic cover to accommodate passengers. Despite the $6^{\text {th }}$ of October is a new city on the western outskirts of GCR, this mode became a part of the mass transport system in the city for the past three decades. Although it is dissatisfactory for the residents, they have no other public transport alternatives. As a result, the search for another mode of transportation is a critical issue for them (UNDP, 2013).
Although there are many master plans that have been submitted for the $6^{\text {th }}$ of October City, transportation has not been focused on as a major axis of development. The transportation process, in general, has always been treated as only the type of movement or commuting and not as an integrated system with the land use master plan. The missing part is how to achieve integration of land use and transportation plan. This problem was clearly articulated upon reviewing all recommendations of previous studies. The following figure shows the latest proposal to link the $6^{\text {th }}$ of October city with the New Administrative Capital. However, this transit suggestion is not yet coordinated with the land use master plan (Figure 6).

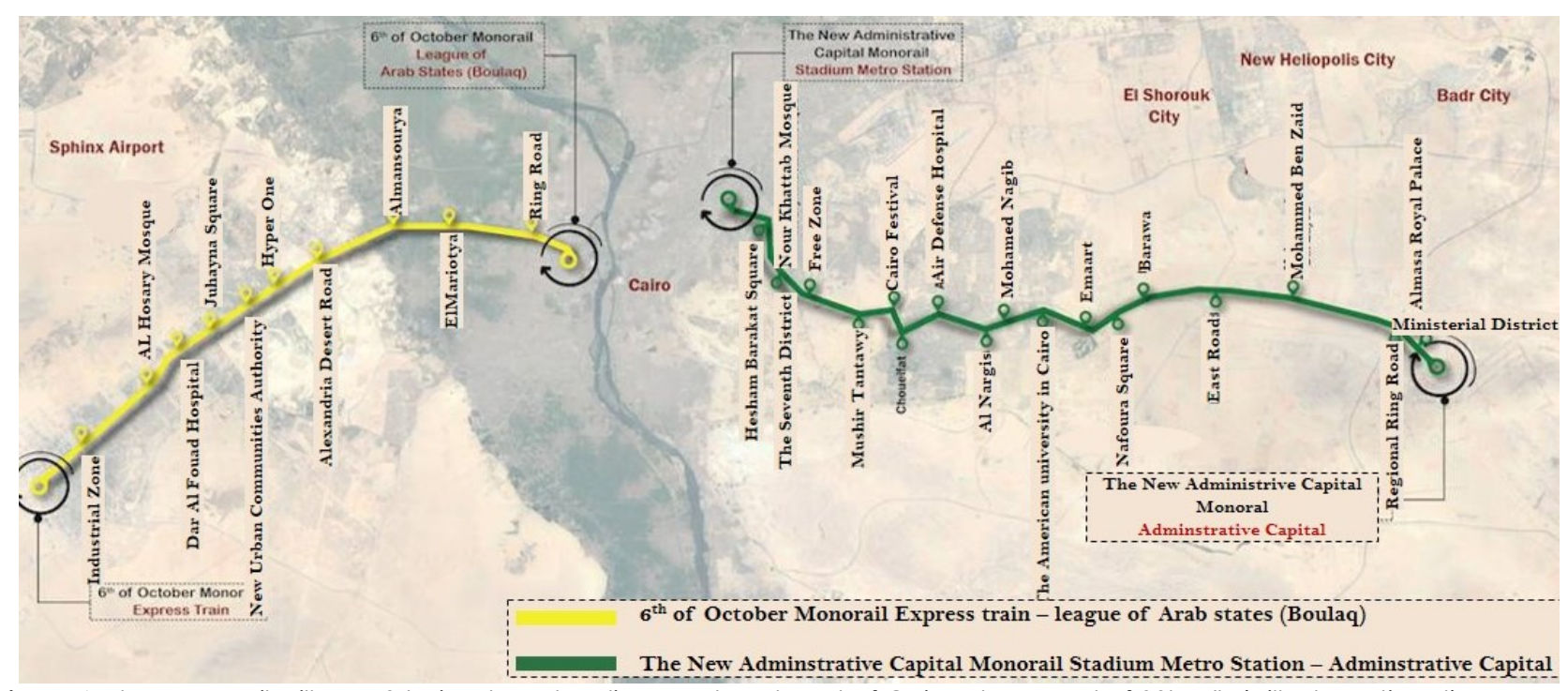

Figure 6. The monorail will run 70 trainsets on two lines east and west of Cairo at a speed of $80 \mathrm{~km} / \mathrm{h}$ (Hill International)- source (Global Construction Review, 2020).

\subsubsection{Giza city, GCR}

Everyday Giza city experiences a large number of incoming and outgoing daily trips, which renders the city one of the most important parts in the Greater Cairo Region. This justifies the presence of the second most important station in the region. Additionally, the location of the El-Giza train station is considered vital because of the existence of both the metro and train lines. However, the critical issue is that the station does not match TOD standards. The following figure shows how the TOD defined catchment area (a $500 \mathrm{~m}$ radius circle surrounding the station) has been compromised due to some mobility barriers (Figure 7). 


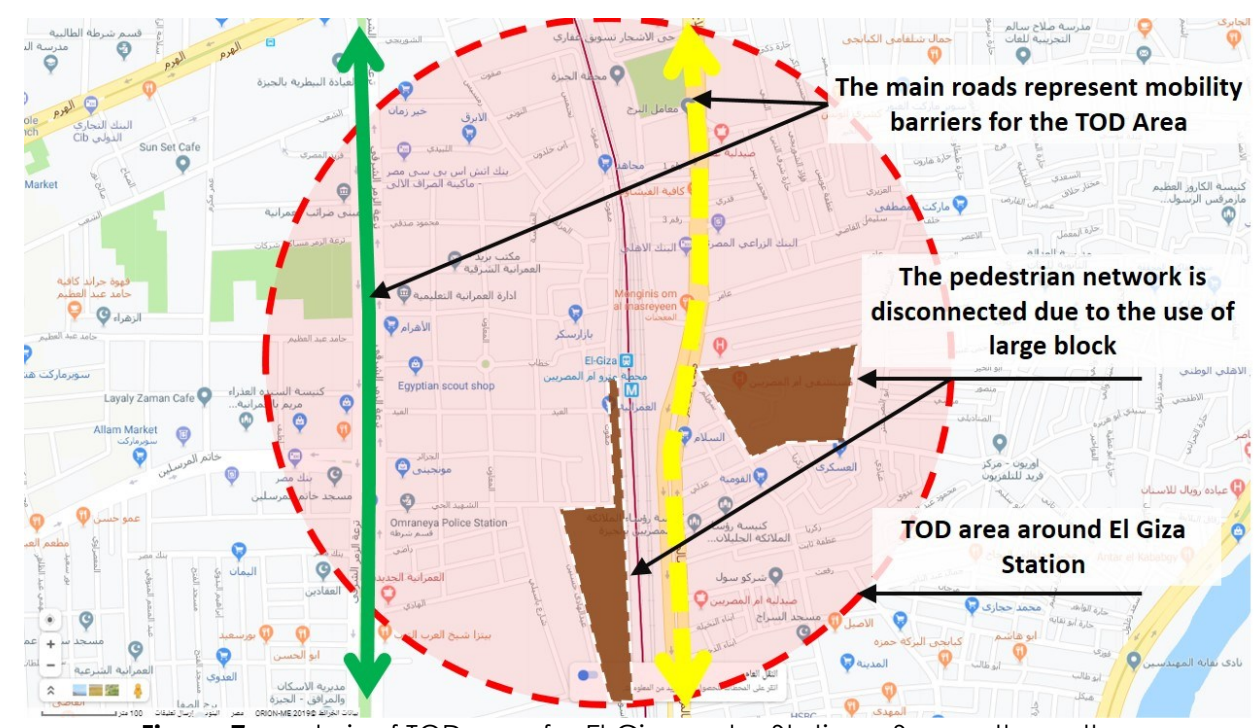

Figure 7. analysis of TOD area for El-Giza metro Station - Source the authors.

\section{Discussion}

The case study analysis of transportation policies in GCR and comparing them to TOD principles have revealed several gaps together with possible potential interventions. Even though many studies have been prepared for Greater Cairo as an attempt to find a solution to the complex traffic congestion problem, all of them focused either only on transportation or on land use planning, but none combined them both under the TOD umbrella. As explained earlier this is not unique to the Egyptian case. This extends to the recently prepared studies for GCR which included good suggestions for planning or transportation, with some of them already implemented. Still, these suggestions need improvement, coordination and integration to be more compatible with the TOD system.

From a management and operation perspective, GCR has several official authorities responsible for all types of public transportation which, overall, might be a positive point. However, that was the main contributor to losing many of GCR's public transportation potentials, as each of them acted individually with a total lack of coordination or integration policies. Hence, providing one qualified institution will be the first step in the right way. A similar issue has been identified by Louafi for Algiers (Louafi, 2019). Additionally, although most daily trips in the GCR are done by public transport, the majority of these trips are done using informal transportation mode, hence outside the jurisdiction or control of public officials and beyond the reach of planning tools.
The detailed analysis of the existing GCR strategy identified some further gaps other than supporting an integrated transport policy and coordinating land use and transport planning. A combination of other modes of transport, including walking, cycling and private vehicles is still lacking. Additionally, adequate policies should start by defining a transportation-planning network not focussing only on providing transportation, but extending to ensure accessibility, affordability, efficiency, safety, and quality. Focusing on public transportation, most of the previous proposed public transportation routes were defined without related urban planning studies contrary to the ideals of TOD. Consequently, the right methodology would be to conduct the urban planning and public transportation network studies simultaneously. Furthermore, the detailed planning for each station location should be done through more accurate studies, where all services and land uses would be distributed in a balanced way. Accordingly, the Los Angeles case can be of use, where a set of design criteria was introduced for how to choose the appropriate station location to be most effective in a TOD system. Meanwhile, a quick comparison between some of the local stations in GCR especially El-Giza station, and the studied international cases, makes it clear that the station disregarded many TOD related benefits because of the lack of the mentioned standards (Figure 7). By reviewing the proposed new metro lines in the $6^{\text {th }}$ of October city and El-Munib area, there will be one exchange station in October and another in ElMunib. It will be very easy to choose a perfect 
location applying TOD criteria in the $6^{\text {th }}$ of October city as the city still has many vacant lands. Contrastingly, El-Munib has a very high residential density and several mobility barriers. Hence, preparing two scenarios for how TOD criteria should be applied in new cities and the existing area is vital and requires urgent further studies.

\section{Conclusion}

To summarise, this paper argued that to present a clear framework or comprehensive strategy that can deal with the massive and complex problems, faced in GCR, it is essential to integrate urban and transportation planning. To understand and determine which type of sustainable development will be most effective and applicable, the paper findings highlighted the adequacy of TOD as most applicable to GCR from among other theories. Within a megacity such as GCR, transport planning is key to achieve several SDGs, specifically ensuring an inclusive and sustainable city (SDG 11). Adopting TOD as the backbone of transport planning is vital to achieve such a goal and improve mobility for all. The city as many cities of the Global South is continuously expanding by both engulfing newly urbanised areas and new urban expansions. Furthermore, many of these new urban areas are serviced through the informal system which needs to be acknowledged and integrated. Hence, the paper concludes by arguing that comprehensive planning with adequate policies is needed to ensure compatibility of formal/informal systems and improve mobility around the city taking affordability, accessibility, efficiency, safety and quality into consideration. The identified gaps in the current transportation planning in GCR serve as lessons learnt, for other cities of the Global South to avoid. The analysis of the global best practices has shown a variety of possible interventions that take into consideration the local circumstances, resources, and needs advocating that there is no "one size fits all". Thus, the suggested interventions and recommendations extracted from the global best practices and a local case could help other cities in their endeavour for better mobility for all. Future studies could fruitfully explore this issue further by developing scenarios for applying TOD principles in different locations, whether within existing compact cities or in new developments.

\section{Acknowledgements}

This research did not receive any specific grant from funding agencies in the public or commercial, or not-for-profit sectors.

\section{Conflict of interests}

The authors declare no conflict of interest.

\section{References}

Boarnet, M., \& Crane, R. C. (2001). Travel by Design: The Influence of Urban Form on Travel. Oxford University Press. https://doi.org/10.1093/oso/9780195123951.003.0 $\underline{008}$

Bohrn, T., \& Buehler, R. (2015). Managing Director, Vienna Regional Public Transport Association. person interview conducted by Ralph Buehler in Vienna, Austria on May, 12, 2015.

Breheny, M. (1996). Centrists, decentrists and compromisers: views on the future of urban form. In Elizabeth Burton, Mike Jenks, \& K. Williams (Eds.), The compact city: A sustainable urban form? (pp. 13-35). E \& FN Spon London.

Buehler, R., Pucher, J., \& Altshuler, A. (2017). Vienna's path to sustainable transport. International Journal of Sustainable Transportation, 11(4), 257-271. https://doi.org/10.1080/15568318.2016.1251997

CTOD. (2010). Creating Successful Transit Oriented Districts in Los Angeles:. Los Angloss: Center For Transit Oriented Development.

De Vos, J., Van Acker, V., \& Witlox, F. (2014). The influence of attitudes on Transit-Oriented Development: An explorative analysis. Transport Policy, 35, 326-329. https://doi.org/10.1016/j.tranpol.2014.04.004

Dock, F. C., \& Swenson, C. J. (2003). Transit-Oriented Urban Design Impacts on Suburban Land Use and Transportation Planning. Transportation Research Record: Journal of the Transportation Research Board, 1831(1), 184-192. https://doi.org/10.3141/1831-21

Downs, A. (2005). Smart Growth: Why We Discuss It More than We Do It. Journal of the American Planning Association, 71(4), 367-378. https://doi.org/10.1080/01944360508976707

Farr, D. (2011). Sustainable Urbanism: Urban Design With Nature. John Wiley \& Sons.

GJEL. (2015). SHOULD BAY AREA CARPOOL LANES $B E \quad$ ENFORCED 24/7? 
https://www.gjel.com/blog/should-bay-areacarpool-lanes-be-enforced-247.html

Global Construction Review.

(2020).

Markets. https://www.globalconstructionreview.com/10000 -man-months-two-years-hill-mobilises-worlds-1/

Hasic, T. (2000). A Sustainable Urban Matrix. In E. Burton, M. Jenks, \& K. Williams (Eds.), Achieving Sustainable Urban Form (pp. 329-336). London: E\&FN Spon.

Herry, M. (2015, May 12). Consultant, Director, Herry Consulting. (R. Buehler, Interviewer) [Interview].

Holden, E. (2004). Ecological footprints and sustainable urban form. Journal of Housing and the Built Environment, 19(1), 91-109. https://doi.org/10.1023/B:JOHO.0000017708.980 $\underline{13 . \mathrm{cb}}$

Høyer, K. G., \& Holden, E. (2003). Household Consumption and Ecological Footprints in Norway - Does Urban Form Matter? Journal of Consumer Policy, 26(3), 327-349. https://doi.org/10.1023/A:1025680422704

IEA. (2015). Energy prices and taxes. New York: International Energy Agency.

IPPUC. (2000). A historia do sistema do transporte coletivo de Curitiba. Curitiba: Instituto de Pesquisa e Planejamento Urbano de Curitiba.

Iravani, H., \& Rao, V. (2020). The effects of New Urbanism on public health. Journal of Urban Design, 25(2), 218-235. https://doi.org/10.1080/13574809.2018.1554997

JICA. (2002). Transportation Master Plan and Feasibility Study of Urban Transport Projects in Greater Cairo Region in the Arab Republic of Egypt. Cairo: Japan International Cooperation Agency. https://openjicareport.jica.go.jp/pdf/11709938_01. pdf

Kaufmann, V. (2011). Rethinking the city: Urban duynamics and motility. Lausanne: EPFL Press distributed by Routledge, Taylor \& Francis.

Kelbaugh, D. (1989). The pedestrian pocket book: A new suburban design strategy. New York: Princeton Architectural Press.

Klink, J., \& Denaldi, R. (2011). Metropolitan Fragmentation and Neo-localism in the Periphery: Revisiting the Case of Curitiba. Urban Studies,
49(3),

$543-561$

https://doi.org/10.1177/0042098011408936

Knoflacher, H. (2015, May 5). Professor Emeritus, Vienna Technical University. (R. Buehler, Interviewer) Vienna [Interview].

LADOT. (2015). LADOT Transit Incentive Fares. Los Angeles: Los Angeles Department of Transportation.

Litman, T. (2015). Analysis of public policies that unintentionally encourage and subsidize urban sprawl. Victoria Transport Policy Institute.

Louafi, O. (2019). The phenomenon of mobility, a development challenge for the city of Algiers. Journal Of Contemporary Urban Affairs, 3(2), 144155. https://doi.org/10.25034/ijcua.2018.4711

MacLeod, G. (2013). New Urbanism/Smart Growth in the Scottish Highlands: Mobile Policies and Postpolitics in Local Development Planning. Urban Studies, 50(11), 2196-2221. https://doi.org/10.1177/0042098013491164

Madreiter, T. (2015, May 11). Vienna's path to sustainable transport. (R. Buehler, Interviewer) Vienna,: International Journal of Sustainable Transportation [Interview].

Mahendra, A. (2018). Balancing accessability with aspiration: Challenges in urban transport planning in the global South. In G. Bhan, S. Srinivas, \& V. Watson (Eds.), The Routledge companion to planning in the global South (pp. 225-240). Routledge. https://doi.org/10.4324/9781317392842-19

Maresch, R. (2015, may 13). Member of Vienna City Parliament, Green Party. In-person. (R. Buehler, Interviewer) [Interview].

Mishra, A. K. (2019). Cities, transport and agglomeration: Addressing the urban mobility challenges in India. Growth and Change, 50(3), 1115-1133. https://doi.org/10.1111/grow.12321

Newman, P. G., \& Kenworthy, J. R. (1989). Cities and automobile dependence: An international sourcebook. Brookfield, VT United States: Gower Publishing.

Nyström, L., \& Fudge, C. (1999). City and Culture: Cultural Processes and Urban Sustainability (Karlskrona: Swedish Urban Environment Council). 
Ossberger, M. (2015, May 8). Director of Infrastructure Asset Management,Linien. (R. Buehler, Interviewer) [Interview].

Pojani, D., \& Stead, D. (2016). A critical deconstruction of the concept of transit oriented development (TOD). REAL CORP proceedings/Tagungsband, 15.

http://pure.tudelft.nl/ws/files/10056669/CORP201 6 33.pdf

Porter, D. R. (2002). Making smart growth work. Washington, DC: Urban Land Institute.

Riedel, R. (2014). Principles of parking management. Zeitschrift fur Verkehrsrecht, 12a, 453-461.

Sammer, G. (2015, May 8-15). Professor Emeritus, $B O K U$ University. (R. Buehler, Interviewer) Vienna, Austria [Interview].

Stefan, A. (2005). The New Urbanism movement: the case of Sweden. Sweden: Blekinge Tekniska Högskola.

Stoel, T. B. (1999). Reining in Urban Sprawl. Environment: Science and Policy for Sustainable Development, 41(4), 6-11. https://doi.org/10.1080/00139159909604624

Transit Cooperative Research Program. (2002). TransitOriented Development and Joint Development in the United States: A Literature Review. http://onlinepubs.trb.org/onlinepubs/tcrp/tcrp rrd $\underline{52 . p d f}$
UNDP. (2013). United Nations Development Programme Global Environment Facility. Egypt: United Nations Development Programme.

United Nations. (2010). Shanghai Manual, A Guide for Sustainable Urban Development. Shanghai: United Nations.

United Nations. (2016). Mobilizing Sustainable Transport for Development. New York: United Nations.

Vassilakou, M. (2015, May 9). Vice-Mayor and Minister of Transport for the City of Vienna, 2010-2015, Green Party. (R. Buehler, Interviewer) [Interview].

World Bank. (2006). Greater Cairo: A Proposed Urban Transport Strategy. 71432, Transport Unit. Arab Republic of Egypt: World Bank Urban.

Yang, L., Majumdar, A., van Dam, K. H., \& Zhang, L. (2021). Theories and practices for reconciling transport infrastructure, public space, and peopleA review. Proceedings of the Institution of Civil Engineers - Municipal Engineer, 1-43. https://doi.org/10.1680/jmuen.20.00037

Ye, L., Mandpe, S., \& Meyer, P. B. (2005). What Is "Smart Growth?"-Really? Journal of Planning Literature, $\quad 19(3), \quad 301-315$ https://doi.org/10.1177/0885412204271668

Youzhen, C., \& Longlong, D. (2012). From Garden City to Smart Growth: The Evolution and Management of New Urbanism. Proceedings of the 2012 International Conference on Public Management (ICPM 2012), 266-271. https://doi.org/10.2991/icpm.2012.32 